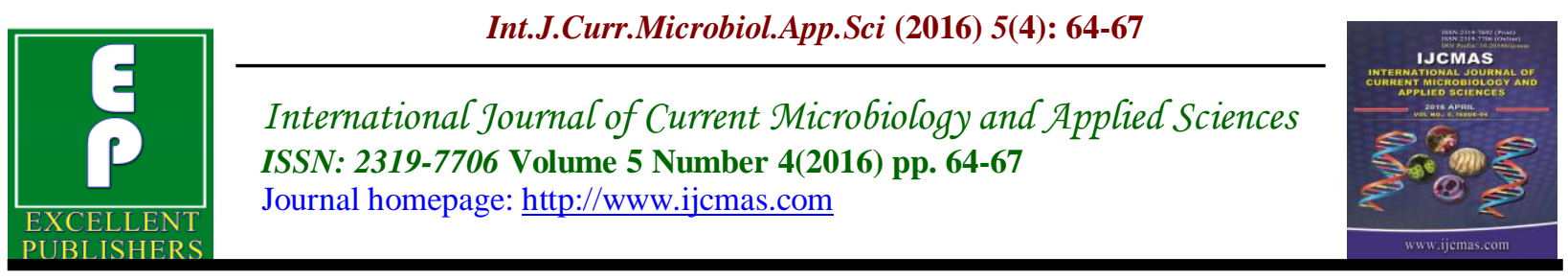

Original Research Article

http://dx.doi.org/10.20546/ijcmas.2016.504.010

\title{
Effect of AM Fungi Funneliformis mosseae on the Growth of Ocimum sanctum
}

\author{
Shweta. B. Jain* and Sunita Chahar \\ Department of Botany, NES Ratnam college of Arts, Science and Commerce, \\ Bhandup west, Mumbai-400078, Maharashtra, India \\ *Corresponding author
}

\begin{abstract}
A B S T R A C T
Keywords

Arbuscular Mycorrhizal Fungi, Ocimium sanctum,

Funneliformis mosseae, Growth.

Article Info

Accepted:

08 March 2016

Available Online:

10 April 2016

AM Fungi are the obligatory symbiotic fungi, which form association with almost $80-90 \%$ of the plants species. AM fungi are known to increase the plant growth by providing the nutrients available in soil to plants. The aim of the experiment was to see the effect of AM Fungi Funneliformis mossesae on the growth of Ocimum sanctum plant. In the Pot culture experiment Ocimum sanctum was grown by sowing seeds. $50 \%$ of the pots were inoculated with spores of Funneliformis mosseae while $50 \%$ were kept as Control. Plants were uprooted after three months and effect of F.mosseae was observed on the parameters like number of leaves, height of the plant, length of root, fresh and dried weight of plant. The results obtained for all the above parameters were significantly more in F.mosseae inoculated plants as compared to control plants. The results revealed that inoculation of mycorrhiza significantly increases the growth of plant and biomass.
\end{abstract}

\section{Introduction}

Ocimum sanctum is a plant having great economical value and is used in Ayurveda as medicine. There are evidences that Ocimum sanctum can address physical, chemical, metabolic and psychological stress through a unique combination of pharmacological actions (Marc Maurice Cohen, 2014). The symbiotic root-fungal association increases the uptake of less mobile nutrients (Ortas et al., 2001), essentially phosphorus (P) but also of micronutrients like zinc ( $\mathrm{Zn})$ and copper $\mathrm{Cu}$. The symbiosis has also been reported as influencing water uptake.
AMF can also benefit plants by stimulating the production of growth regulating substances, increasing photosynthesis, improving osmotic adjustment under drought and salinity stresses and increasing resistance to pests and soil borne diseases (Al-Karaki, 2006). These benefits are mainly attributed to improved phosphorous nutrition (Plenchette et al., 2005). The ability of VAM fungi to enhance host-plant uptake of relatively immobile nutrients, in particular phosphorus and several micronutrients, has been the most recognized beneficial effect of mycorrhizae. 
VAM fungi have the potential to reduce damage caused by soil borne pathogenic fungi, nematodes and bacteria. AMF may be useful in the development of effective methods of plant cultivation and may improve the quality and quantity of obtained material (Khaosaad et al., 2006; Muthukumar et al., 2006)

\section{Materials and Method}

\section{Experimental Design}

3 sets of Mycorrhizal and Non- Mycorrhizal pots were taken each containing $5 \mathrm{~kg}$ of substrate soil: sand in the ratio of $3: 1$ and $50 \mathrm{gm}$ of coco peat was added in each pot.

5 gms of Funneliformis mosseae containing 50 spores were inoculated at the time of germination of seeds.

The plants were watered every alternate day.

The plants were uprooted 90 days after sowing and analysed for growth parameters

Root Colonization: It was checked by Phillips and Hayman's method, 1970.
Spore Extraction: Spore count was done by Gerdeman and Nicolson's method, 1963

Mycorrhizal Inoculation Effect:. It was calculated by the following formula (Bagyaraj et al., 1988).

MIE = Dry weight of inoculated plants Dry weight of non-inoculated plants / Dry weight of inoculated plants X 100

\section{Results and Discussion}

The Fresh weight of leaves and shoots was checked immediately after uprooting. The dry weight was taken after drying the plant material at $72^{\circ} \mathrm{C}$ for $48 \mathrm{hrs}$. The results given in table 1 show that shoot length, root length and number of leaves of Mycorrhizal plants was more than that of control plants, also the fresh weight and dry weight of the Mycorrhizal plants was more as compared to control plants. Our results of the present experiment confirm reports on enhanced plant growth due to AM inoculation to medicinal plants (Earanna, 2001; Bobby and Bagyaraj, 2003; Nisha and Rajeshkumar, 2010; Vasanthakrishna et al., 1995; Rajan et al., 2000, H.S Seema et al., 2015).

Table.1

\begin{tabular}{|c|c|c|c|c|c|c|c|c|c|}
\hline $\begin{array}{c}\text { Sr } \\
\text { No. }\end{array}$ & $\begin{array}{c}\text { Type of } \\
\text { plant }\end{array}$ & $\begin{array}{l}\text { Description } \\
\text { (Each pot } \\
\text { containing } 5 \\
\text { plants) }\end{array}$ & $\begin{array}{l}\text { Stem length } \\
(\mathrm{cm})\end{array}$ & $\begin{array}{l}\text { Root length } \\
(\mathbf{c m})\end{array}$ & $\begin{array}{l}\text { Number of } \\
\text { leaves }\end{array}$ & $\begin{array}{c}\text { Fresh } \\
\text { weight of } \\
\text { stem of } \\
\text { all } \\
\text { plants(g) }\end{array}$ & $\begin{array}{c}\text { Dry } \\
\text { weight } \\
\text { of all } \\
\text { stems } \\
\text { (g) }\end{array}$ & $\begin{array}{l}\text { Fresh } \\
\text { weight } \\
\text { of all } \\
\text { leaves } \\
\text { (g) }\end{array}$ & $\begin{array}{c}\text { Dry } \\
\text { weight } \\
\text { of all } \\
\text { leaves } \\
\text { (g) }\end{array}$ \\
\hline 1 & \multirow{3}{*}{$\begin{array}{c}\text { Mycorrhizal } \\
\text { Plant }\end{array}$} & pot 1 & $11.100 \pm 1.517$ & $8.900 \pm 0.894$ & $13.000 \pm 1.581$ & \multirow{3}{*}{2.4380} & \multirow{3}{*}{0.553} & \multirow{3}{*}{6.755} & \multirow{3}{*}{1.074} \\
\hline 2 & & pot 2 & $12.400 \pm 2.074$ & $11.800 \pm 2.864$ & $21.000 \pm 7.450$ & & & & \\
\hline 3 & & pot 3 & $11.200 \pm 1.095$ & $11.400 \pm 0.894$ & $17.000 \pm 2.915$ & & & & \\
\hline 4 & \multirow{3}{*}{$\begin{array}{c}\text { Non- } \\
\text { Mycorrhizal } \\
\text { Plant }\end{array}$} & pot 1 & $11.600 \pm 1.817$ & $7.000 \pm 2.739$ & $9.600 \pm 1.817$ & \multirow{3}{*}{1.402} & \multirow{3}{*}{0.220} & \multirow{3}{*}{3.980} & \multirow{3}{*}{0.625} \\
\hline 5 & & pot 2 & $10.000 \pm 1.871$ & $8.200 \pm 2.387$ & $11.400 \pm 0.894$ & & & & \\
\hline 6 & & pot 3 & $10.200 \pm 1.483$ & $6.400 \pm 1.140$ & $11.600 \pm 2.302$ & & & & \\
\hline
\end{tabular}




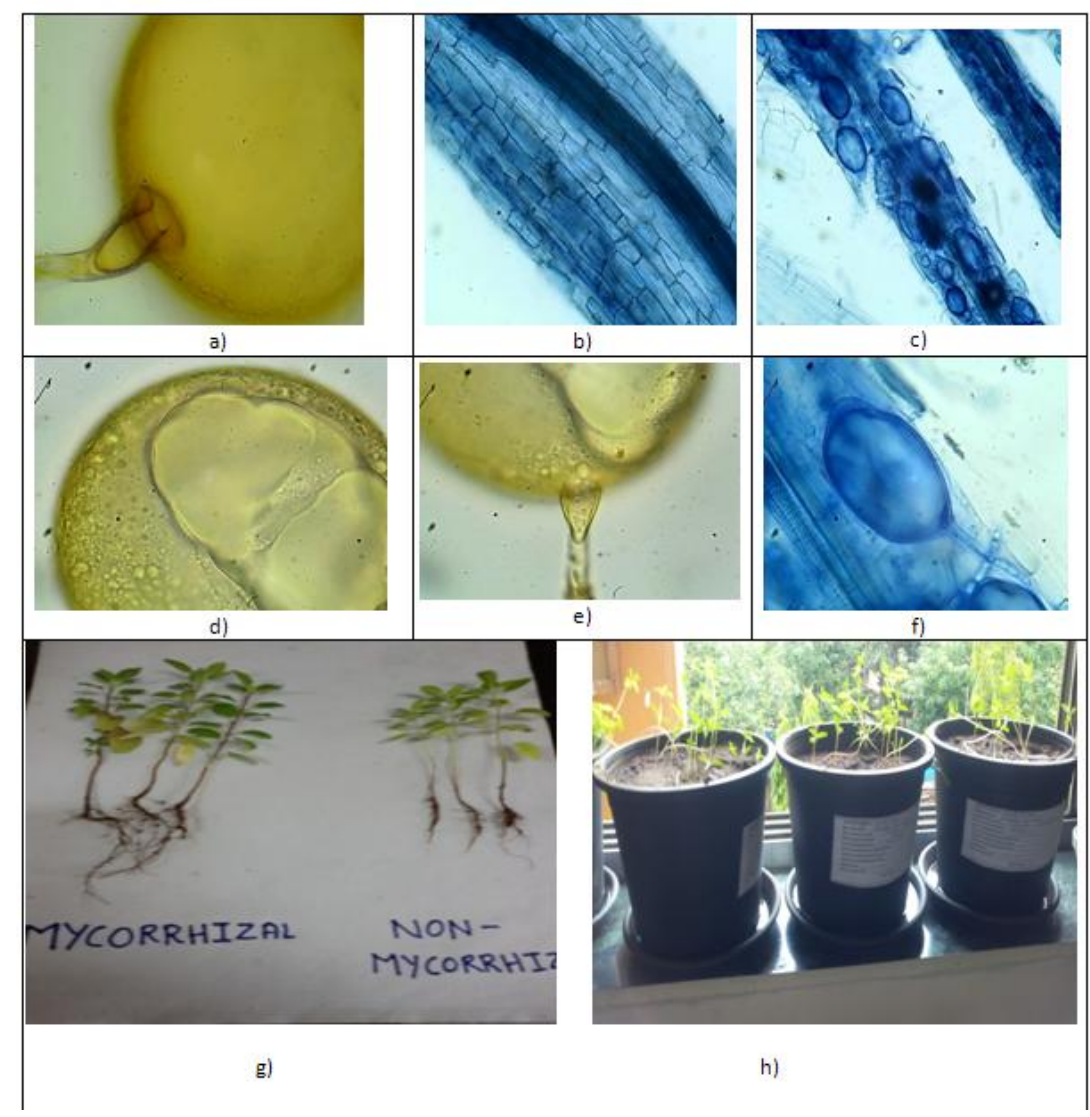

a) Mycorrhizal spore isolated from inoculum of TERI (Funneliformis mosseae) b) Control Ocimum sanctum roots stained with trypan blue c) roots showing infecton of mycorrhiza (Funneliformis mosseae) stained with trypan blue. d) Mycorrhizal spore isolated from inoculated pot after 90 days e) Mycorrhizal spore isolated from inoculated pot after 90 days with hyphae f) Root stained with trypan blue showing presence of vesicle g) Mycorrhizal and control plant showing difference in their growth h) Ocimum sanctum pots.

The Mycorrhizal Inoculation Effect (MIE) is a parameter to assess the growth improvement brought about by inoculation with a mycorrhizal fungus. MIE of F.mosseae in O.sanctum was found to be 48 $\%$ (H.S seema et al., 2015).

\section{Spore Density}

50 spores in $5 \mathrm{~kg}$ of soil was added. After 90days spore density was found to be 60 spores per 20gm of soil, which is much higher compared to the results obtained by Mala et al., 2010.

\section{Structural change in the Mycorrhizal spore}

The spores of Funneliformis mosseae obtained from pure culture of TERI did not show oil globules whereas after three months of association with Ocimum sanctum, the spores showed presence of big oil globules in it.

\section{Mycorrhizal Infection in the Roots}

The percentage infection in root was found to be $90 \%$ in the form of arbuscules, vesicles and hyphae.

In conclusion, inoculation of Mycorrhiza (F.mosseae) in O.sanctum increases the shoot length, root length, number of leaves and dry weight, fresh weight of plants by $50 \%$. The substrate used for growing plant i.e soil: sand: cocopeat was found to be 
effective in pots having capacity of carrying $5 \mathrm{Kg}$ soil. Oil globules were very prominently seen in the spores after 90 days of infection in the plant.

\section{Acknowledgement}

The authors would like to acknowledge NES Ratnam college Bhandup(west) for providing the laboratory support. We are obliged to The Energy and Resources Institute (TERI) for providing us pure inoculum of F.mosseae.

\section{References}

Bagyaraj, F.J., Manjunath, A., Govinda, Y.S. 1988. Mycorrhizal inoculation effect on different crops. J. Soil Biol. Ecol., 8: 98103.

Gaur, A., Adholeya, A. 1994. Mycorrhiza News. 6: 10-11.

Gerdemann, J.W., Nicolson, T.H. 1963. Spores of mycorrhizal endogone species extracted from soil by wet sieving and decanting. Trans. Br. Mycol. Soc., 46: 235-244.

Seema, H.S., Rajkumar, H., Garampalli. 2015. Effect of Arbuscular Mycorrhizal fungi on growth and biomass enhancement in Piper longum L. (Piperaceae), Int. J. Curr. Microbiol. App. Sci., 4(1): 11-18. In: Mycorrhizae: biofertilizers for the future. Proc. 3rd Natn. Conf. on Mycorrhiza-1995. (Eds. Adholeya, A. and Singh, S.) pp. 119-23. TERI, New Delhi.

Kumar, et al. 2013. Ocimum sanctum (Tulsi): a miracle herb and boon to medical science - A Review Int. J. Agronomy and Pl. Product, Volume 4(7): 1580-1589.

Marc Maurice Cohen, 2014. Tulsi - Ocimum sanctum: A herb for all reason $\mathrm{J}$ Ayurveda Integr Med. Oct-Dec; 5(4): 251-259. doi: 10.4103/09759476.146554

Muthukumar, T., Senthilkumar, M., Rajangam, M., Udaiyan, K. 2006. Arbuscular mycorrhizal morphology and dark septate fungal associations in medicinal and aromatic plants of Western Ghats, Southern India. Mycorrhiza, 17: 11-24.

Phillips, J.M., Hayman, D.S. 1970. Improved procedures for clearing roots and staining parasitic and vesicular arbuscular mycorrhizal fungi for rapid assessment of colonization. Trans. Br. Mycol. Soc., 55: 158-160.

Plenchette, C., Fortin, J.A., Furlan, V. 1983. Growth response of several plants species to mycorrhiza in a soil of moderate $\mathrm{P}$ fertility mycorrhizal dependency under field condition. Pl. Soil, 70: 191-209.

Smith, S.E., Read, D.J. 1997. Mineral nutrition, heavy metal accumulation and water relations in VA mycorrhizal plants Mycorrhizal Symbiosis, 2nd Ed., Academic Press, San Diego, CA, p. 126160.

Mala, W.J., Kumari, I.S., Sumanasena, H.A., Nanayakkara, C.M. 2010. Effective Spore Density of Glomus mosseae, Arbuscular Mycorrhiza (AM), for Inoculation of Rooted Cuttings of Black Pepper (Piper nigrum Linn.) Trop. Agri. Res., Vol. 21(2): 189-197.

\section{How to cite this article:}

Shweta. B. Jain and Sunita Chahar. 2016. Effect of AM Fungi Funneliformis mosseae on the Growth of Ocimum sanctum.Int.J.Curr.Microbiol.App.Sci. 5(4): 64-67. doi: http://dx.doi.org/10.20546/ijcmas.2016.504.010 